\title{
The toxicity of lithium to human cardiomyocytes
}

\author{
Junwei Shen ${ }^{1,2+}$, Xin $\mathrm{Li}^{3+}$, Xiujuan Shi ${ }^{1}$, Wei Wang ${ }^{1}$, Hua Zhou ${ }^{3}$, Jiawen Wu ${ }^{1}$, Xin Wang ${ }^{3}$ and Jue $\mathrm{Li}^{1,2^{*}}$ (B)
}

\begin{abstract}
Background: Lithium is widely used in the electronic consumer market and electric vehicles and has a great contribution to the world economy, resulting in large quantities of lithium waste in the environment. The Yangtze River Basin is one of the most developed areas in China. However, the environmental influence of lithium in the Yangtze River Basin and its roles in cardiomyocytes have not yet been clarified.

Results: Here, we found that the concentration of lithium in the water environment is very high in Shanghai, as well as in tap water, which might be caused by the pollution of lithium batteries. Lithium inhibits cell viability and proliferation of human cardiomyocytes. Moreover, lithium promotes cell apoptosis significantly. And we found that lithium controls cardiomyocytes' functions through regulating glycogen synthase kinase 3 beta signaling.

Conclusions: This study reveals that the water environment of Shanghai might be polluted by the lithium batteries; and the enrichment of lithium might cause damage to human cardiomyocytes. It is imperative to detect lithium concentration in the water environments (such as tap water and irrigation water) and effectively recycle lithium batteries in the future.
\end{abstract}

Keywords: Lithium, Pollution, The Yangtze River Basin, Cardiomyocyte

\section{Background}

Lithium is the first element in the alkali metal group and the lightest metal. It is very active; therefore, it exists mainly in the form of compounds (such as apatite or aluminum silicide) in the environment [1-4]. The other two elements in the alkali metal group, sodium and potassium, account for more than $2 \%$ in the earth's crust; however, in contrast to them, the existence of lithium on the earth is scarce, counting only $0.0065 \%[5,6]$. Although lithium may also be enriched in several mines and salt lakes, it is usually widely spread in trace amounts in rocks and soils, as well as in water, including surface water, groundwater, and seawater [7]. For example, the content

\footnotetext{
*Correspondence: lijue0923@sina.com

†Junwei Shen and Xin Li contributed equally to this article

${ }^{2}$ Institute of Clinical Epidemiology and Evidence-Based Medicine, Tongji University School of Medicine, No. 1239 Siping Road, Shanghai 200092, China

Full list of author information is available at the end of the article
}

in seawater is very low, only $0.17 \mathrm{mg} / \mathrm{L}$. In freshwater, the content is scarce, less than $0.04 \mathrm{mg} / \mathrm{L}$ [7]. The lithium compounds are highly soluble; therefore the main form of lithium in water is ion [8]. Since the concentration of lithium in the natural environment is generally very low, it does not cause damage to the environment.

However, since the first commercial lithium battery was invented in 1991, it has rapidly become popular and is widely used in consumer electronics such as laptop computers, smartphones, and tablet computers $[9,10]$. The large-scale application of lithium batteries makes a great contribution to the world economy [11]. However, it might cause lots of lithium pollution. In cities, lithium batteries are routinely discarded in the environment, along with other solid garbage [10]. The lithium batteries are still cheap enough to throw old batteries and obtain virgin material [10]. Therefore, the recycling rate is meager, even in developed countries that do well in environmental protection [10]. The rapid increase in consumption and the serious shortage of recycling might 
lead to continuous accumulation of lithium in the developed areas where lithium is broadly used.

As one of the most economically developed regions in China, the Yangtze River Basin has a GDP accounting for two-fifths of China [12]. It contains a series of megacities, including Shanghai, Suzhou, Changsha, Nanjing, Wuhan and Chongqing. This region has a well-developed electronic consumer market and rapid economic growth, which continues to promote lithium consumption. However, the research on the impact of lithium pollution in the Yangtze River Basin has not yet been reported to date. Shanghai, at the estuary of the Yangtze River, is the leader of the Chinese economy. Shanghai is one of the biggest consumer electronics market in China. Besides, Shanghai is actively promoting the popularization of electric vehicles these years [13]. The facts above increase substantially the use of lithium batteries, which accumulates the lithium pollution in this area. Due to the discharge of large quantities of lithium resources, lithium pollution is growing rapidly and imposing a severe threat to the environment and humans [14].

Though the low concentration of lithium has no harmful effect on the environment, at higher levels lithium may cause considerable damage to the aquatic and terrestrial environment [15]. For example, a small dose of lithium has a significant inhibitory effect on the proliferation and growth of aquatic organisms including Pimephales promelas, Ceriodaphnia dubia, and Elimia clavaeformis [16]. Also, lithium in water can accumulate in plants and cause damage to plant growth and development $[17,18]$. For example, $60 \mathrm{mmol} / \mathrm{L}$ of lithium can damage the growth of sunflower; the same concentration can also affect the growth of corn [17]. Lithium can be enriched in animals by food chains, and high concentrations of lithium can also cause severe damage to animals [19]. For instance, rats were treated with small doses of lithium for 7 weeks (every alternate day) [20]. The epithelium lining of renal tissue was injured, and some significant changes were observed in the glomerular region in the corticomedullary region [20]. Besides, high concentrations of lithium could cause severe damage to humans, including the nervous system (including coarse tremor and hyperreflexia), kidney (including sodium-losing nephritis and nephrotic syndrome), and endocrine system (including hypothyroidism) [21-24]. However, the effects of lithium on the cardiovascular system have not been studied yet.

As one of the most important organs in our body, the heart is the first organ that functions in the embryo development. It is exposed to an open environment that contains various types of harmful factors, such as nicotine, alcohol and drugs. Notably, the cardiomyocytes that contracts in the heart, lacks regeneration capability [25]. Therefore, each damage to the cardiomyocytes could accumulate constantly during the lifetime. Moreover, the damage to cardiac contractility might be irreversible. Therefore, cardiotoxicity becomes the most important cause for the recall of prescription drugs [26]. It accounts approximately half of all drugs withdrawn in the last two decades [26]. For example, the obesity treatment drug sibutramine and the antidiabetic drug rosiglitazone were both recalled due to their cardiotoxicity effects in 2010 [27, 28]. However, the effects of lithium on cardiomyocytes remain to be determined. Our research detected that lithium concentrations in the Yangtze River and rivers in Shanghai are relatively high, and it is possible to cause harm to human health through food chains [29]. Then we found that lithium not only significantly inhibited cell viability and cell proliferation of human cardiomyocytes, but also promoted cell apoptosis. Finally, we found that these effects of lithium may be related to the regulation of GSK3 3 .

\section{Materials and methods}

\section{Detection of the concentration of lithium in water}

The water samples were obtained from the places shown in Fig. 1e. The concentration of lithium in water samples was detected with K-Lite8F (Cornley, Meizhou, China) according to the manual. To evaluate the effects of lithium batteries on water, two disabled Apple 6s plus batteries and two disabled Huawei P20 pro batteries were used in this study. Each battery was placed in a beaker, soaked in ultrapure water, and then the battery is punctured with a clean needle, then added ultrapure water to $2 \mathrm{~L}$. After 3 days, the polluted water was filtered by filter paper. The concentration of lithium in these samples was detected with K-Lite8F (Cornley) as well.

\footnotetext{
(See figure on next page.)

Fig. 1 Lithium enrichment in Shanghai water environment. a Pie chart shows the sales of electric vehicle worldwide in 2018. b Histogram shows the China electric vehicle sales and growth rate from 2012 to 2018. c Pie chart shows the demand for electric vehicles worldwide in 2017. d Histogram shows the electric vehicles in Shanghai from 2014 to 2018. e Schematic diagram shows the six water environments. (1) Yangtze river, (2) freshwater lake, (3) pit lake, (4) Suzhou River, (5) Dingpu River, (6) Chongming island. f Histogram shows the concentration of lithium in the six water environments. $\mathbf{g}$ Histogram shows the concentration of lithium in Tongji pure water and tap water. $\mathbf{h}$ Histogram shows the concentration of lithium in ultrapure water, Apple 6s plus and Huawei P20 pro
} 


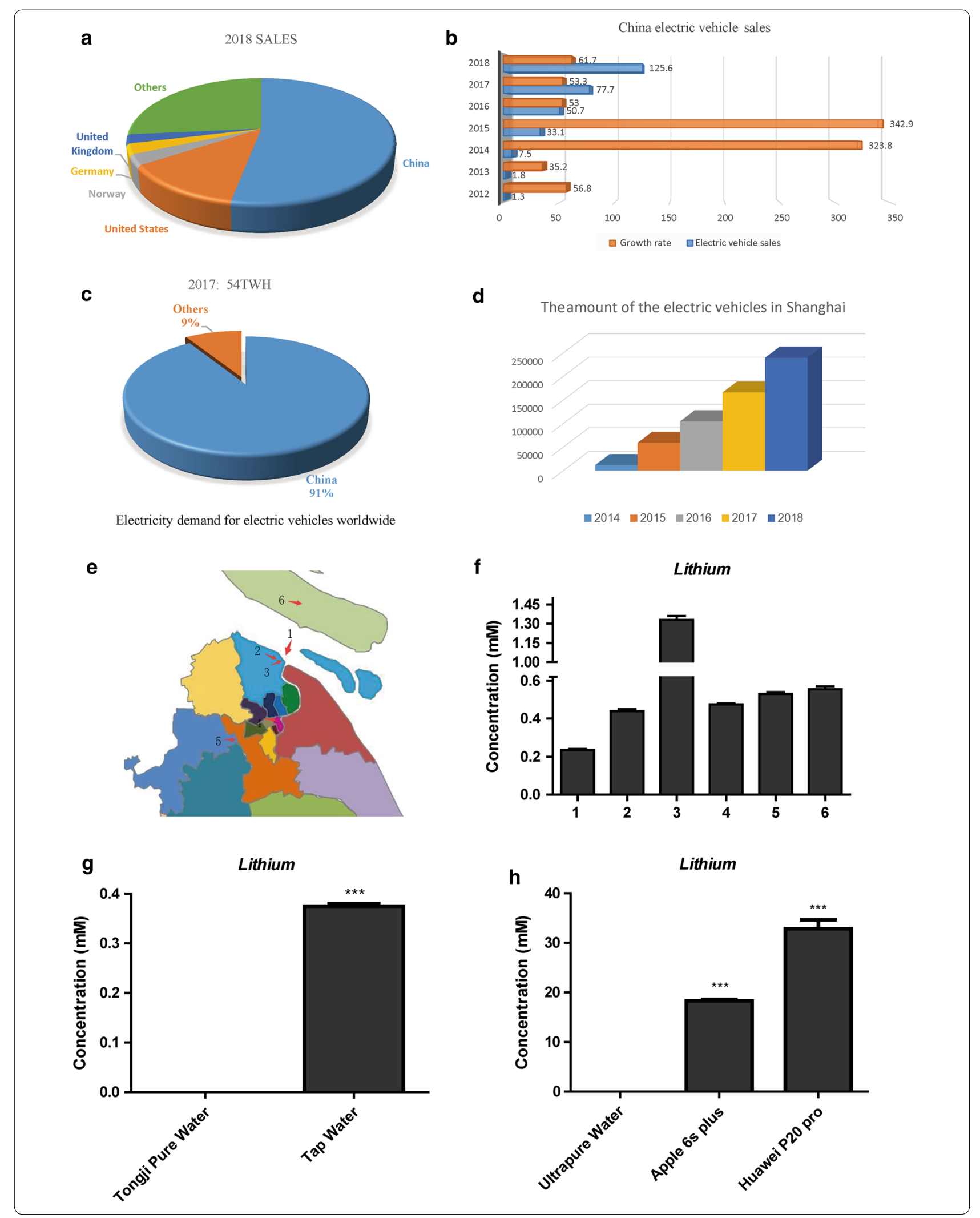




\section{Cell culture and treatment}

Human AC16 cardiomyocyte line was cultured in highglucose Dulbecco's modified Eagle's medium (Gibco, Grand Island, NY) supplemented with $10 \%$ (v/v) fetal bovine serum (Gibco) and 1\% (v/v) penicillin and streptomycin (Gibco). Cells were grown in a humidified atmosphere of $5 \% \mathrm{CO}_{2}$ at $37^{\circ} \mathrm{C}$. $\mathrm{LiCl}$ (Sinopharm Chemical Reagent, Shanghai, China) or $\mathrm{Li}_{2} \mathrm{SO}_{4}$ (Sinopharm Chemical Reagent, Shanghai, China) was reconstituted in $\mathrm{ddH}_{2} \mathrm{O}$. AC16 cells were incubated with $\mathrm{LiCl}$ or $\mathrm{Li}_{2} \mathrm{SO}_{4}$ at different concentrations $(0.2 \mathrm{mmol} / \mathrm{L}, 1 \mathrm{mmol} / \mathrm{L}$, $5 \mathrm{mmol} / \mathrm{L}$ or $25 \mathrm{mmol} / \mathrm{L}$ ) for $48 \mathrm{~h}$ as specified in the figure legends.

\section{Cell viability assay}

The cell viability was tested with CellTiter-Lumi ${ }^{\mathrm{TM}}$ Luminescent Cell Viability Assay Kit (Beyotime, Nantong, China). The AC16 cells were seeded into 96-well plates $\left(1 \times 10^{3}\right.$ cells/well $)$ [30]. After $48 \mathrm{~h}$ treatment with control $\left(\mathrm{ddH}_{2} \mathrm{O}\right), \mathrm{LiCl}, \mathrm{NaCl}$ or $\mathrm{Li}_{2} \mathrm{SO}_{4}$ at different concentrations $(0.2 \mathrm{mmol} / \mathrm{L}, 1 \mathrm{mmol} / \mathrm{L}, 5 \mathrm{mmol} / \mathrm{L}$ or $25 \mathrm{mmol} / \mathrm{L})$, the cells were assessed. $100 \mu \mathrm{L}$ CellTiter-Lumi ${ }^{\mathrm{TM}}$ reagent was added into each well of the plate. Then the plate was incubated at $37^{\circ} \mathrm{C}$ for $10 \mathrm{~min}$. The luminometer was subsequently recorded with SpectraMax M5 plate reader (Molecular Devices).

The cell viability was measured via the Cell Counting Kit-8 (CCK-8) assay as well. AC16 cells were seeded into 96-well plates $\left(1 \times 10^{3}\right.$ cells/well) [31]. After $48 \mathrm{~h}$ treatment with control, $\mathrm{LiCl}, \mathrm{NaCl}$ or $\mathrm{Li}_{2} \mathrm{SO}_{4}$ at different concentrations $(0.2 \mathrm{mmol} / \mathrm{L}, 1 \mathrm{mmol} / \mathrm{L}, 5 \mathrm{mmol} / \mathrm{L}$ or $25 \mathrm{mmol} / \mathrm{L}$ ), the cells were assessed. $10 \mu \mathrm{L}$ CCK- 8 reagent (Dojindo, Kumamoto, Japan) was added into each well of the plate. Then the plate was incubated at $37{ }^{\circ} \mathrm{C}$ for $2 \mathrm{~h}$. The absorbance at $450 \mathrm{~nm}$ was subsequently recorded with SpectraMax M5 plate reader (Molecular Devices).

\section{Cell apoptosis assay}

AC16 cells were treated with control, $5 \mathrm{mmol} / \mathrm{L} \mathrm{LiCl}$ or $2.5 \mathrm{mmol} / \mathrm{L} \mathrm{Li}_{2} \mathrm{SO}_{4}$ for $48 \mathrm{~h}$. To quantify the cell apoptotic degree, the harvested cells were stained with annexin V-FITC/PI Cell Apoptosis Kit (Keygen, Nanjing, China) according to the manufacturer's instructions. After incubation for $30 \mathrm{~min}$ at $4{ }^{\circ} \mathrm{C}$, the cells were analyzed using FCM (FACS Canto; BD Biosciences).

\section{EdU proliferation assay}

5-Ethynyl-2'-deoxyuridine (EdU) is a synthetic thymidine analog that can incorporate into newly synthesized DNA during $\mathrm{S}$ phase. Therefore, EdU detection can be used for tracking DNA replication directly [32]. The immunofluorescence staining of EdU was performed with BeyoClick ${ }^{\mathrm{TM}}$ EdU-555 proliferation kit (Beyotime) followed the Kit manual. Briefly, cells were cultured in 24-well plates, fixed in $4 \%$ paraformaldehyde after $48 \mathrm{~h}$ treatment with control, $5 \mathrm{mmol} / \mathrm{L} \mathrm{LiCl}$ or $2.5 \mathrm{mmol} / \mathrm{L}$ $\mathrm{Li}_{2} \mathrm{SO}_{4}$, and permeabilized with $0.2 \%$ Triton X-100 for $15 \mathrm{~min}$. Cells were counterstained with Hoechst for $5 \mathrm{~min}$, then were washed with and imaged in PBS. At last, the images were taken using fluorescence microscopy (Nikon).

\section{Western blotting}

Cultured AC16 cells were lysed in strong RIPA buffer containing Halt Protease Inhibitor Cocktails (Thermo, Waltham, MA). Protein concentrations were measured using a BCA protein assay kit (Pierce, Rockford, IL). Primary antibodies targeting proliferating cell nuclear antigen (PCNA) (ab29, abcam, Cambridge, UK), tumor protein p53 (TP53) (ab1101, abcam), CYCLIN E (ab33911, abcam), glycogen synthase kinase 3 beta

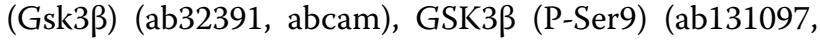
abcam) and glyceraldehyde-3-phosphate dehydrogenase (GAPDH) (ab9485, abcam) were incubated with proteins overnight at $4{ }^{\circ} \mathrm{C}$, followed by incubation with the appropriate HRP (horseradish peroxidase) conjugated secondary antibodies (BA1038 and BA1039, Boster, Wuhan, China). Detection of HRP was performed using the ECL assay kit (Beyotime) and an ImageQuant LAS $4000 \mathrm{mini}$ (GE, Boston, Unite States).

\section{Statistical analysis}

GraphPad Prism 7.0 software was used for statistical analysis. Statistical significance between two groups was determined using an unpaired two-tailed Student's $t$ test. Data are presented as mean \pm SD (standard deviation) or mean \pm SEM (standard error of the mean) as indicated in the figure legends. $p$ values were considered statistically significant if $p<0.05$.

\section{Results}

The enrichment of lithium in Shanghai water environment To investigate the potential pollution of lithium in China, we evaluated the electric vehicle market in 2018. Surprisingly, China accounts for more than half of the global market (Fig. 1a). At the same time, the electric vehicle market in China is growing rapidly these years (Fig. 1b). China accounts for $91 \%$ of the world's lithium battery demand in 2017 due to the huge electric vehicles, electric bikes and electric buses (Fig. 1c). Shanghai is one of the most active cities to promote the development of electric vehicles. The number of electric vehicles was more than 100,000 in 2016 in Shanghai, making it the largest electric vehicle city that time (Fig. 1d). 
The previous results suggest that Shanghai could become a region with lithium pollution, therefore we detected the lithium concentration in different water environments (Fig. 1e, f). Though the concentration of lithium in Yangtze River $(1.80 \mathrm{mg} / \mathrm{L})$ was the lowest in the six environments (Fig. 1e, f), it was much higher than the normal concentration in freshwater $(0.04 \mathrm{mg} / \mathrm{L})$ [7]. The concentrations of lithium in other water environments were much higher than in the Yangtze River (Fig. 1e, f), and concentration of lithium in the pit lake was the highest. Intriguingly, compared with lithium in pure water $(0 \mathrm{mmol} / \mathrm{L})$, the lithium concentration in tap water was a little high $(0.37 \mathrm{mmol} / \mathrm{L})$. Lithium concentration in the water that was contaminated by lithium batteries was very high (Fig. 1g). These data indicated that the water environment in Shanghai could be polluted by lithium batteries.

Lithium inhibits the cell viability of human cardiomyocytes To investigate the effects of lithium on cardiomyocytes, we evaluated the cell viability of AC16 cells under $\mathrm{LiCl}$ exposure at different concentrations $(0 \mathrm{mmol} / \mathrm{L}$, $0.2 \mathrm{mmol} / \mathrm{L}, 1 \mathrm{mmol} / \mathrm{L}, 5 \mathrm{mmol} / \mathrm{L}$ or $25 \mathrm{mmol} / \mathrm{L})$. Compared to the control $(0 \mathrm{mmol} / \mathrm{L})$, the growth of $\mathrm{AC} 16$ cells was significantly inhibited by $\mathrm{LiCl}$ at concentrations of $5 \mathrm{mmol} / \mathrm{L}$ and $25 \mathrm{mmol} / \mathrm{L}$ with the luminescent assay, as well as the CCK- 8 assay (Fig. $2 \mathrm{a}-\mathrm{c}$ ). To evaluate whether $\mathrm{Cl}^{-}$causes the inhibitory effects, $\mathrm{NaCl}$ was added in the study. Interestingly, high dose of $\mathrm{NaCl}$ had no significant effect on cell viability of AC16 cells (Fig. 2d-f). Additionally, we observed that $\mathrm{Li}_{2} \mathrm{SO}_{4}$ at concentrations of $2.5 \mathrm{mmol} / \mathrm{L}$ and $12.5 \mathrm{mmol} / \mathrm{L}$ also obviously inhibited the cell viability of AC16 cells (Fig. $2 g-i$ ). Thus, these data suggested that lithium may exert adverse effects on cardiomyocytes to inhibit cell viability.

\section{Lithium inhibits the cell proliferation of human cardiomyocytes}

EdU proliferation assay showed that the EdU level in the $5 \mathrm{mmol} / \mathrm{L} \mathrm{LiCl}$ treated group was significantly reduced, suggesting that the cell proliferation rate of AC16 cells reduce sharply (Fig. 3a). Similarly, $2.5 \mathrm{mmol} / \mathrm{L} \mathrm{Li}_{2} \mathrm{SO}_{4}$ also inhibited AC16 cell proliferation dramatically (Fig. 3b). Then we evaluated the cell proliferation ability by cell counting. Consistently, the lithium repressed the AC16 cell proliferation significantly (Fig. 3c, d). Proliferating cell nuclear antigen (PCNA) is an essential cofactor for DNA polymerases during replication [33]. We showed that the protein expression of PCNA in AC16 cells reduced significantly after $48 \mathrm{~h}$ treatment with $\mathrm{LiCl}$ or $\mathrm{Li}_{2} \mathrm{SO}_{4}$ compared to the control (Fig. 3e, f).

\section{Lithium triggers the cell apoptosis of human cardiomyocytes}

To further evaluate the effects of lithium on cardiomyocytes, we test the cell apoptosis with Annexin V-FITC/ PI apoptosis assay. AC16 cell apoptosis increased significantly after $48 \mathrm{~h}$ treatment with $5 \mathrm{mmol} / \mathrm{L} \mathrm{LiCl} \mathrm{compared}$ to the control (Fig. 4a, b). Consistently, we observed that $2.5 \mathrm{mmol} / \mathrm{L} \mathrm{Li}_{2} \mathrm{SO}_{4}$ also induced AC16 cell apoptosis (Fig. 4c, d). These data suggest that lithium might promote the cell apoptosis of human cardiomyocytes.

\section{Lithium controls human cardiomyocytes via Gsk3 $\beta$ signaling}

TP53 is an apoptosis marker. Western blot analysis revealed that $5 \mathrm{mmol} / \mathrm{L} \mathrm{LiCl}$ or $\mathrm{Li}_{2} \mathrm{SO}_{4}$ treatment for $48 \mathrm{~h}$ significantly increased the expression levels of TP53 in AC16 cells (Fig. 5a, b). Cyclin E is a proliferation marker. Cyclin $\mathrm{E}$ protein levels decreased after $5 \mathrm{mmol} / \mathrm{L} \mathrm{LiCl}$ or $\mathrm{Li}_{2} \mathrm{SO}_{4}$ treatment for $48 \mathrm{~h}$ compared with the control (Fig. 5c, d). It is reported that glycogen synthase kinase 3 beta $(\mathrm{Gsk} 3 \beta)$ is active regulator of cell proliferation and

\footnotetext{
(See figure on next page.)

Fig. 2 Lithium suppresses the cell viability of human cardiomyocytes. a Microscopic images of AC16 cells treated with control (0 mmol/L) and LiCl at different concentrations $(0.2 \mathrm{mmol} / \mathrm{L}, 1 \mathrm{mmol} / \mathrm{L}, 5 \mathrm{mmol} / \mathrm{L}$ or $25 \mathrm{mmol} / \mathrm{L})$ for $48 \mathrm{~h}$. Bars $=200 \mu \mathrm{m}$. b Influence of LiCl at different concentrations $(0 \mathrm{mmol} / \mathrm{L}, 0.2 \mathrm{mmol} / \mathrm{L}, 1 \mathrm{mmol} / \mathrm{L}, 5 \mathrm{mmol} / \mathrm{L}$ or $25 \mathrm{mmol} / \mathrm{L})$ on cell viability of AC16 cells as measured by luminescence assay $48 \mathrm{~h}$ post-cell seeding. The data are represented as mean $\pm \operatorname{SEM}(n=3) .{ }^{* * *} p<0.001 . \mathbf{c}$ Influence of LiCl at different concentrations $(0 \mathrm{mmol} / \mathrm{L}, 0.2 \mathrm{mmol} / \mathrm{L}, 1 \mathrm{mmol} / \mathrm{L}$, $5 \mathrm{mmol} / \mathrm{L}$ or $25 \mathrm{mmol} / \mathrm{L}$ ) on cell viability of AC16 cells as measured by CCK-8 assay $48 \mathrm{~h}$ post-cell seeding. The data are represented as mean \pm SEM $(n=3) .{ }^{* *} p<0.001$. d Microscopic images of AC16 cells treated with control $(0 \mathrm{mmol} / \mathrm{L})$ and $\mathrm{NaCl}$ at different concentrations $(0.2 \mathrm{mmol} / \mathrm{L}$, $1 \mathrm{mmol} / \mathrm{L}, 5 \mathrm{mmol} / \mathrm{L}$ or $25 \mathrm{mmol} / \mathrm{L})$ for $48 \mathrm{~h}$. Bars $=200 \mu \mathrm{m}$. e Influence of $\mathrm{NaCl}$ at different concentrations $(0 \mathrm{mmol} / \mathrm{L}, 0.2 \mathrm{mmol} / \mathrm{L}, 1 \mathrm{mmol} / \mathrm{L}$, $5 \mathrm{mmol} / \mathrm{L}$ or $25 \mathrm{mmol} / \mathrm{L})$ on cell viability of AC16 cells as measured by luminescence assay $48 \mathrm{~h}$ post-cell seeding. The data are represented as mean $\pm \operatorname{SEM}(n=3) .{ }^{* * *} p<0.001 . \mathbf{f}$ Influence of $\mathrm{NaCl}$ at different concentrations $(0 \mathrm{mmol} / \mathrm{L}, 0.2 \mathrm{mmol} / \mathrm{L}, 1 \mathrm{mmol} / \mathrm{L}, 5 \mathrm{mmol} / \mathrm{L}$ or $25 \mathrm{mmol} / \mathrm{L})$ on cell viability of AC 16 cells as measured by CCK- 8 assay $48 \mathrm{~h}$ post-cell seeding. The data are represented as mean $\pm \mathrm{SEM}(n=3)$. ${ }^{*} p<0.05,{ }^{* *} p<0.01$, ${ }^{* * *} p<0.001$. g Microscopic images of AC16 cells treated with control $(0 \mathrm{mmol} / \mathrm{L})$ and $\mathrm{Li}_{2} \mathrm{SO}_{4}$ at different concentrations $(0.1 \mathrm{mmol} / \mathrm{L}, 0.5 \mathrm{mmol} / \mathrm{L}$, $2.5 \mathrm{mmol} / \mathrm{L}$ or $12.5 \mathrm{mmol} / \mathrm{L})$ for $48 \mathrm{~h}$. Bars $=200 \mu \mathrm{m}$. h Influence of $\mathrm{Li}_{2} \mathrm{SO}_{4}$ at different concentrations $(0 \mathrm{mmol} / \mathrm{L}, 0.1 \mathrm{mmol} / \mathrm{L}, 0.5 \mathrm{mmol} / \mathrm{L}$, $2.5 \mathrm{mmol} / \mathrm{L}$ or $12.5 \mathrm{mmol} / \mathrm{L}$ ) on cell viability of AC16 cells as measured by luminescence assay $48 \mathrm{~h}$ post-cell seeding. The data are represented as mean $\pm \operatorname{SEM}(n=3)$. ${ }^{* * *} p<0.001$. i Influence of $\mathrm{Li}_{2} \mathrm{SO}_{4}$ at different concentrations $(0 \mathrm{mmol} / \mathrm{L}, 0.1 \mathrm{mmol} / \mathrm{L}, 0.5 \mathrm{mmol} / \mathrm{L}, 2.5 \mathrm{mmol} / \mathrm{L}$ or $12.5 \mathrm{mmol} / \mathrm{L})$ on cell viability of AC 16 cells as measured by CCK- 8 assay $48 \mathrm{~h}$ post-cell seeding. The data are represented as mean $\pm \mathrm{SEM}(n=3)$. ${ }^{*} p<0.05$, ${ }^{* *} p<0.01,{ }^{* *} p<0.001$
} 

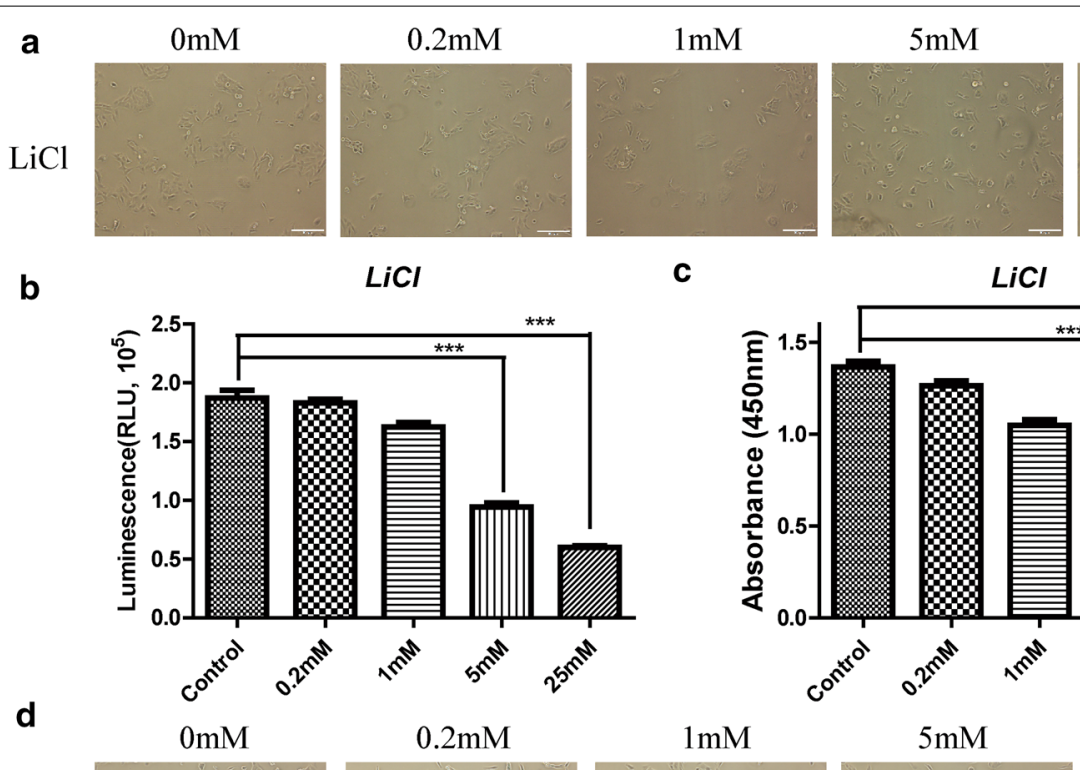

$25 \mathrm{mM}$

C
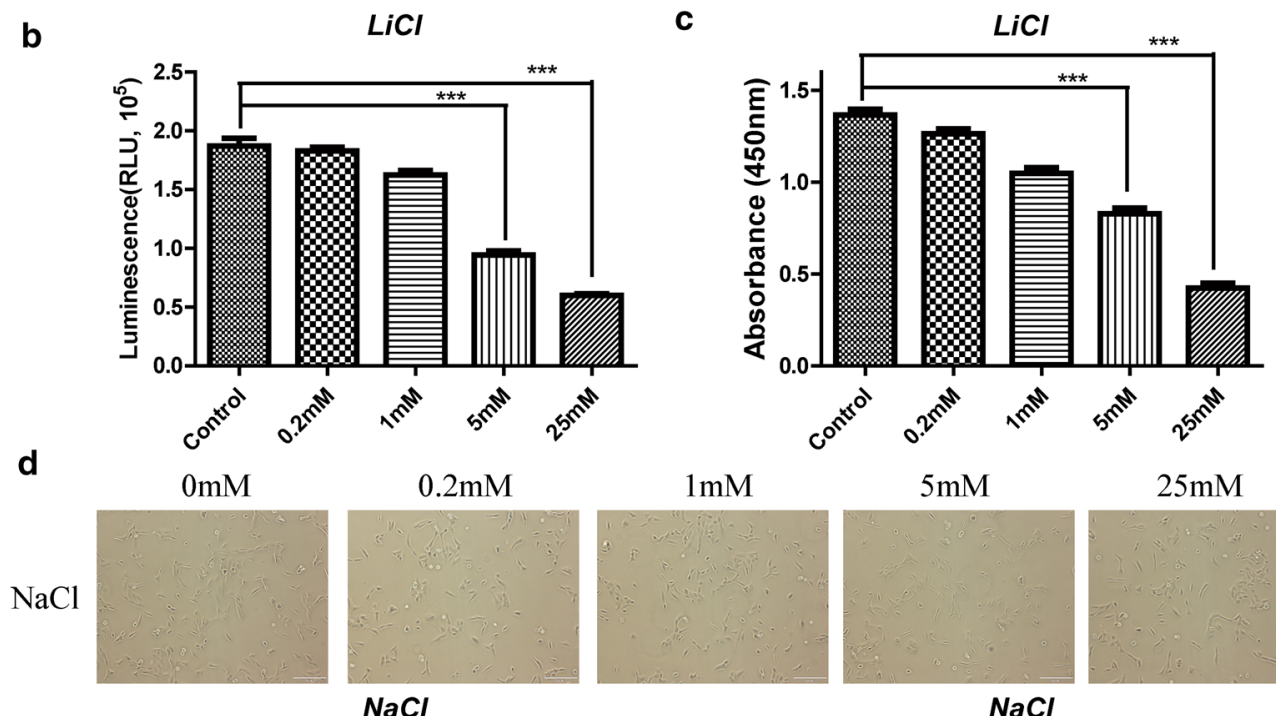

e

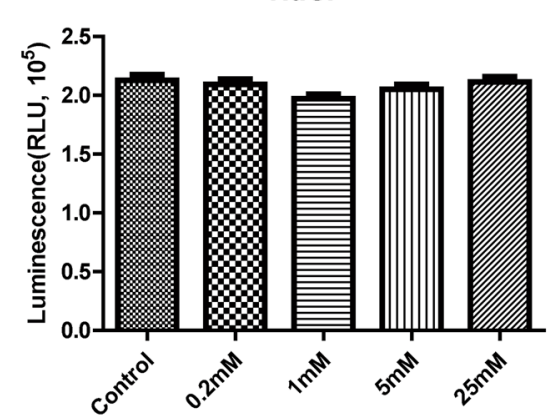

$1 \mathrm{mM}$

$5 \mathrm{mM}$

$25 \mathrm{mM}$

g

$0 \mathrm{mM}$

$0.1 \mathrm{mM}$

f

$\mathrm{NaCl}$
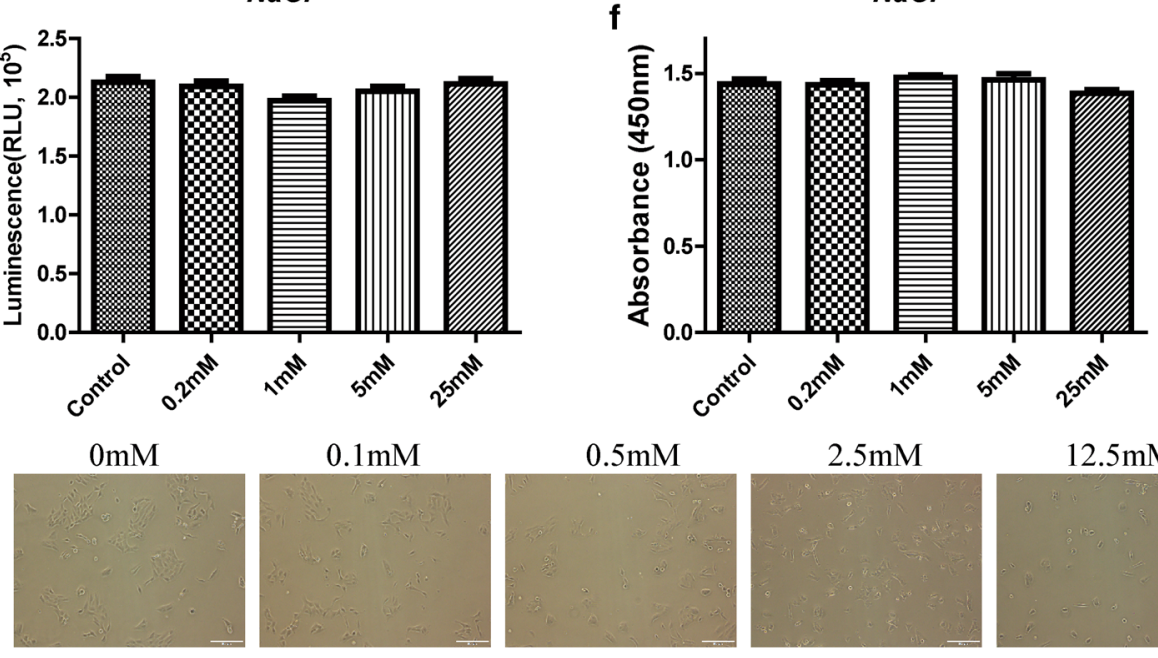

$0.5 \mathrm{mM}$

$2.5 \mathrm{mM}$

$12.5 \mathrm{mM}$

$\mathrm{Li}_{2} \mathrm{SO}_{4}$

h

$\mathrm{Li}_{2} \mathrm{SO}_{4}$

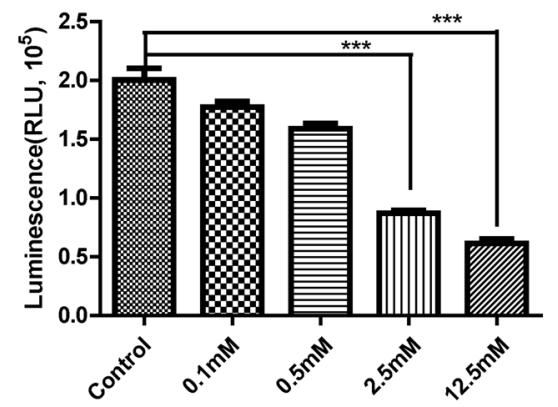

i $\mathrm{Li}_{2} \mathrm{SO}_{4}$

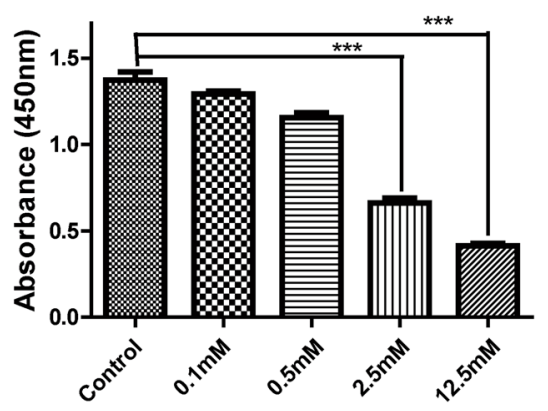




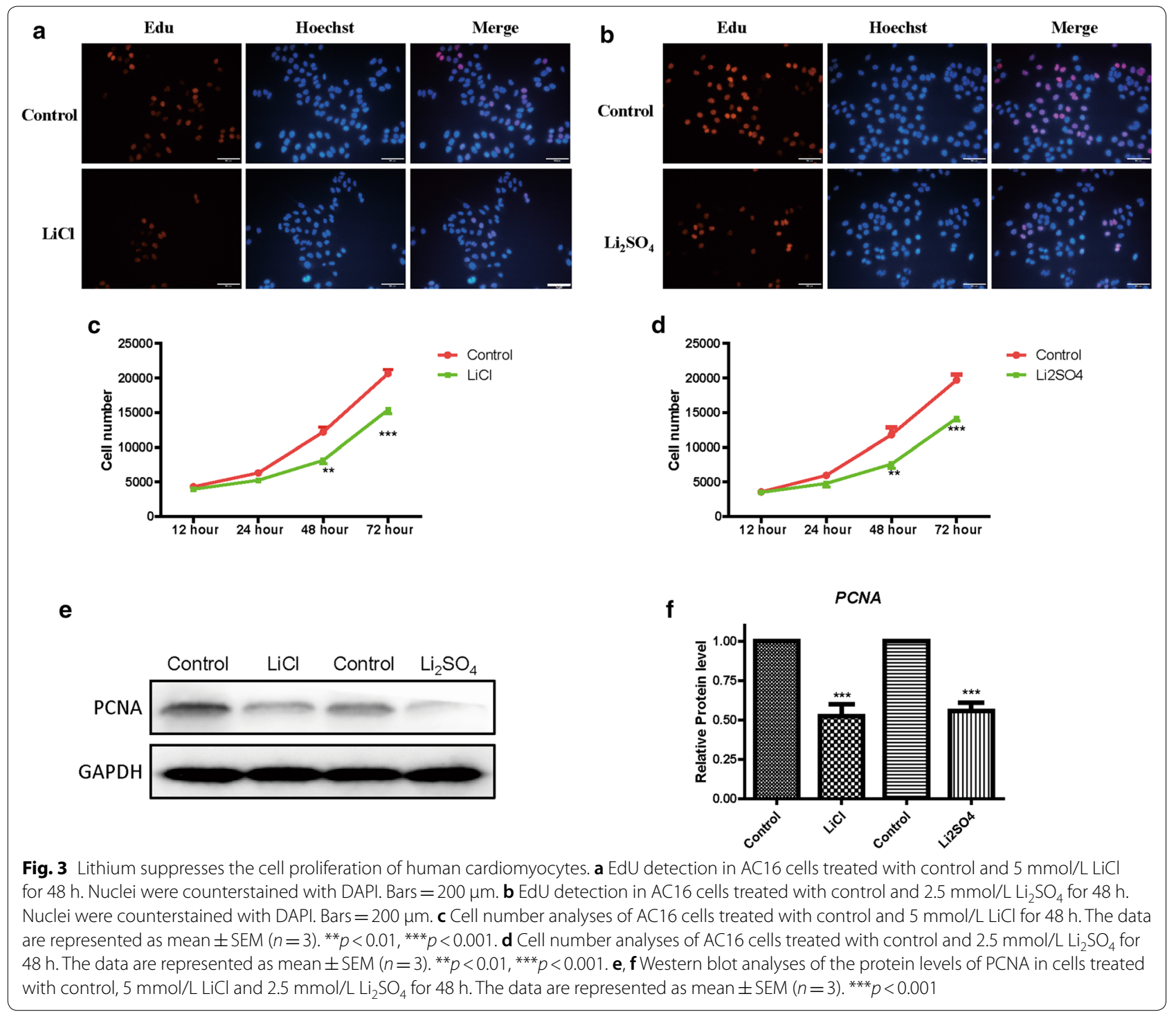

apoptosis; therefore we test the change of Gsk3 $\beta$ after lithium treatment. We incubated AC16 cells with $\mathrm{LiCl}$ or $\mathrm{Li}_{2} \mathrm{SO}_{4}$ for $48 \mathrm{~h}$ and examined the protein levels of Gsk3 $\beta$ and phosphorylated Gsk3 $\beta$ (S9) via western blotting. Interestingly, it showed that $\mathrm{LiCl}$ or $\mathrm{Li}_{2} \mathrm{SO}_{4}$ treatment for $48 \mathrm{~h}$ elevated pGsk3 $\beta$ level significantly (Fig. $5 \mathrm{e}, \mathrm{f}$ ). These results suggest that lithium could control human cardiomyocytes through Gsk3 $\beta$ signaling.

\section{Discussion}

The balance between drug efficacy and cardiotoxicity becomes crucial for clinical trials [26]. Here, we demonstrated that a high concentration of lithium, treatment of bipolar affective disorder, could not only suppress the cell viability of human cardiomyocytes, but also promote cell apoptosis. Adult cardiomyocytes losing proliferation ability, lack efficient repair when they are injured [25]. Therefore, the slight damage to cardiomyocytes could be accumulated year by year. Importantly, the effects of lithium are long-duration accumulation. For instance, lithium-induced nephropathy seems to be a very slowly progressive disease, and the average period from the initiation of lithium to the presence of end-stage kidney disease is a least 20 years [21]. The toxicity of lithium on the central nervous system and renal has been studied extensively. However, the researches about the chronic poisoning of lithium on the heart remain far from enough. Therefore, it is necessary to pay attention to the large-scale clinical 

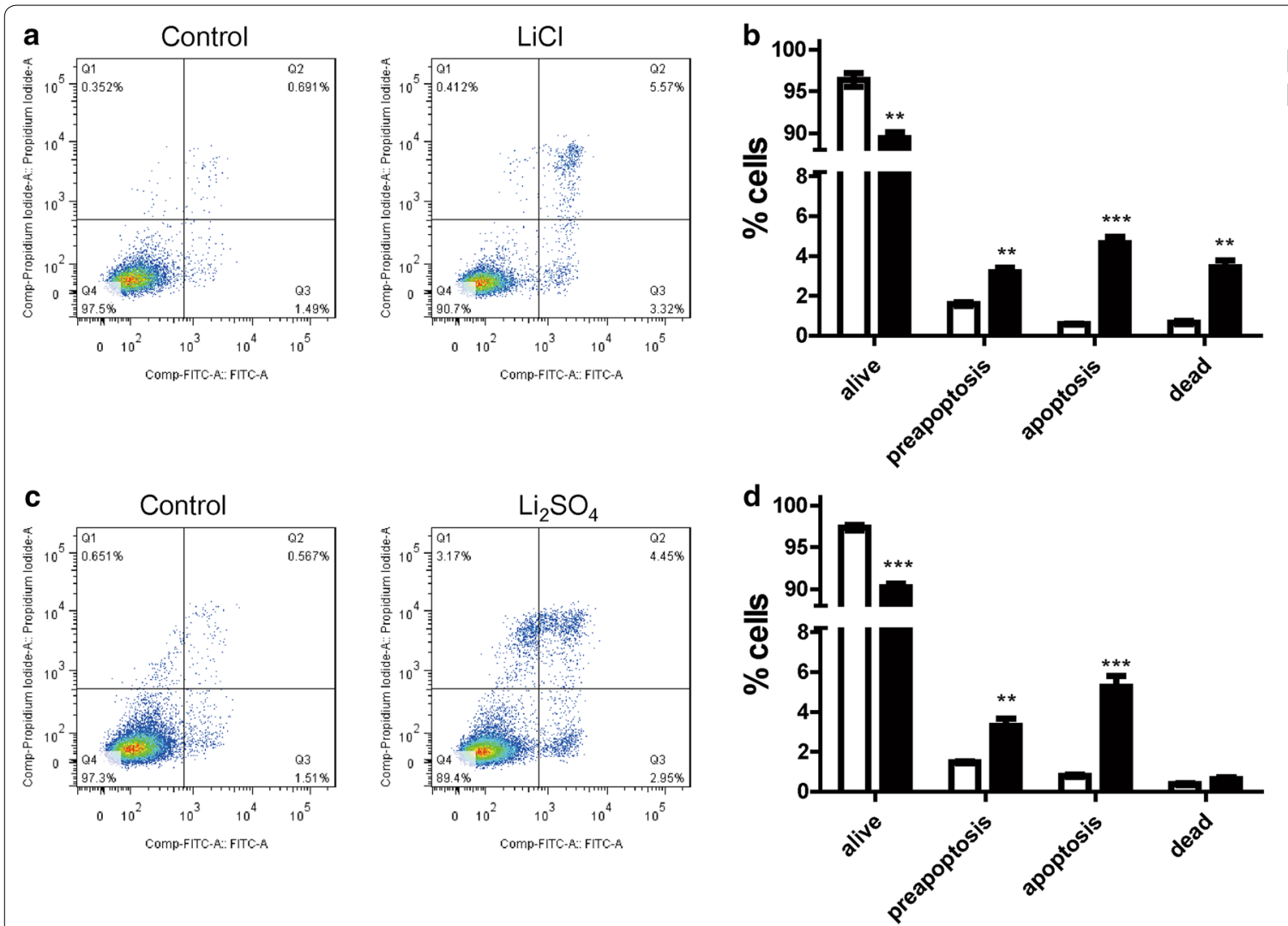

Fig. 4 Lithium triggers the cell apoptosis of human cardiomyocytes. a Comparison of AC16 cell apoptosis treated with control or $5 \mathrm{mmol} / \mathrm{L} \mathrm{LiCl}$ for $48 \mathrm{~h}$ via annexin V-FITC/PI apoptosis assay. $\mathbf{b}$ Statistical analyses of the apoptotic cells in $\mathbf{a}$. The data are represented as mean $\pm S E M(n=3)$. ${ }^{* *} p<0.01,{ }^{* *} p<0.001$. c Comparison of AC16 cell apoptosis treated with control or $2.5 \mathrm{mmol} / \mathrm{L} \mathrm{Li}_{2} \mathrm{SO}_{4}$ for $48 \mathrm{~h}$ via annexin V-FITC/PI apoptosis assay. d Statistical analyses of the apoptotic cells in $\mathbf{c}$. The data are represented as mean $\pm \operatorname{SEM}(n=3) .{ }^{* *} p<0.01,{ }^{* * *} p<0.001$

investigation to detect the damage of lithium to the heart.

It is a fact that the roles of lithium on humans are confusing. It is an important medication option treatment for patients with bipolar disorder [34]. However, the plasma lithium level must be carefully monitored and kept to a narrow range $(0.5-1.2 \mathrm{mmol} / \mathrm{L})$ to avoid acute poisoning, such as confusion, seizures and encephalopathy [35]. In addition to acute poisoning, chronic poisoning is the most common side-effect, including reduced urinary concentrating ability, hypothyroidism and weight gain [36]. At the cellular level, lithium reduced cell growth of cancer cells in a dose-dependent manner [37]. Besides, lithium could induce brain iron accumulation and promotes neurodegeneration [38]. These findings, together with our work, suggest the toxicity that we need to pay attention to. In contrast to these defects, low-dose lithium is very important for animals. For instance, it plays an especially important role during early fetal development [39]. In humans, lithium deficiency is associated with increased rates of suicides, homicides and other crimes [39]. Besides, low-dose lithium could protect neurons via inhibiting cell apoptosis [40-42]. Taken together, it is of interest to investigate the roles of low-dose lithium on cardiomyocytes in vitro.

We intake lithium from dietary foods and drinking water, since it is widespread in soils and waters in the earth's crust [7]. Usually, the lithium we intake daily is less than $3 \mathrm{mg}$, and it might be good for health [39]. Importantly, the lithium level in drinking water, almost negligible at 30 years of age, increases sharply (tap water in Shanghai $0.37 \mathrm{mmol} / \mathrm{L}$ ), especially for the people living in lithium-rich regions (up to $100 \mathrm{mg} / \mathrm{L}$ ) [39]. The level of lithium in tap water is much higher than before. Therefore, the lithium we intake increases markedly daily. It is reported that several genes are significantly changing under this level [43]. But the level is much lower than the toxic concentration to humans. Therefore, it could have rare adverse effects on normal adults. However, in lithium-rich regions, the adverse effects need to be determined for specific people such as children who are $2-3$ years old. They drink water half as adults drink, while 


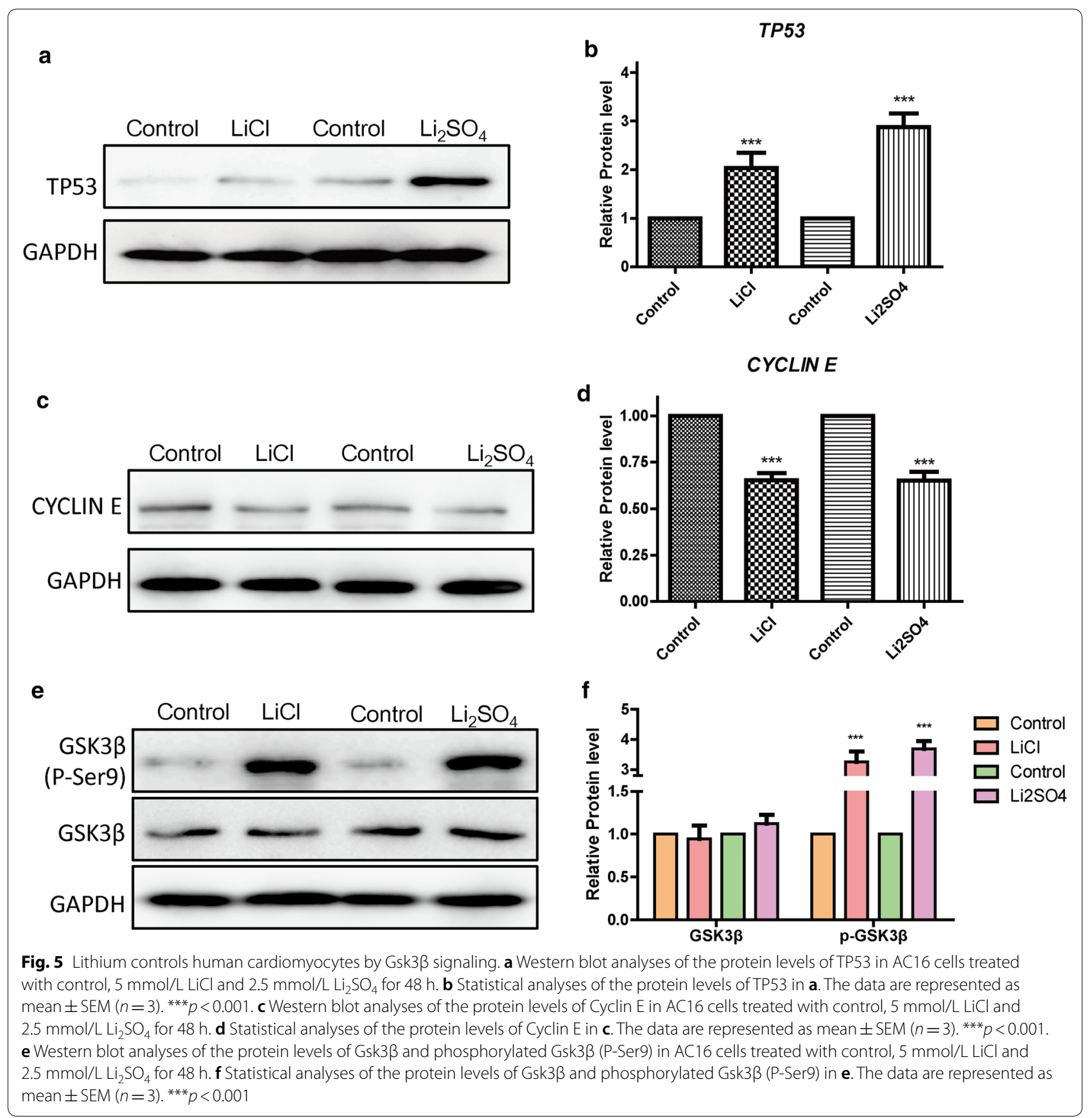

their weigh far less than adults. Notably, the development of their nervous system and kidney is immature. Therefore, they are the potential victims of lithium pollution.

Lithium pollution is a new environmental problem that appeared after the 1990s. This study, together with previous researches, confirms that a high concentration of lithium could cause serious injury to the environment and humans, which needs to be paid more attention to $[17,44,45]$. However, at present, the indicators of environmental monitoring, such as the detection of soil and water, do not include lithium in the Yangtze River Basin. It needs to add lithium as an indicator as soon as possible, especially in the vulnerable areas. Besides, adding the detection of lithium in agricultural irrigation water is particularly important because it is not only closely associated with the crops, but also with our health [44]. Lithium has been listed as a pollutant that leads to environmental harm in irrigation water supplies 
in Australia [10]. The concentration of lithium entering waterways should be less than or equal to $2.5 \mathrm{mg} / \mathrm{L}$ [10]. Therefore, it should be added in this area as quickly as possible in the future. In addition to detection, recycling is an effective approach to reduce lithium pollution in the next 20 years [46-48]. To this end, one possible method is to collect taxes on lithium batteries. It could raise the price of lithium batteries, which might improve the benefits of lithium recycling. Therefore, it can not only reduce the waste of resources, but also increase environmental protection. In addition, garbage classification is currently emerging in China, including Shanghai and Beijing. It is a fundamental method for garbage recycling. Thus, the classification and recycling of lithium batteries will significantly increase the efficiency of lithium resources and reduce environmental pollution.

There are some shortages that need to be improved in this study. For example, we found that lithium may affect the activity of cardiomyocytes by regulating the GSK3 $\beta$ pathway. Intriguingly, it is reported that the mechanism of lithium changes with different concentrations. At a concentration of $2 \mathrm{mmol} / \mathrm{L}$, it inhibits GSK-3 directly, while at a concentration of $0.8 \mathrm{mmol} / \mathrm{L}$, it regulates protein kinase B (PKB) [49]. Besides, it is reported that lithium could promote protein-coding RNAs that interacted with Alzheimer's disease-associated genes [50]. Furthermore, lithium might interact with adenosine triphosphate (ATP) and form a bimetallic (Mg.Li) ATP complex [51]. Therefore, the mechanism of lithium on cardiomyocytes might be multifaceted. On the other hand, since the water flow in the Yangzi River is constantly changing in the four seasons, the concentration of lithium is changing as well. Therefore, more work will be required to detect it all through the year in the future. Besides, we found that $5 \mathrm{mmol} / \mathrm{L}$ lithium inhibited cell viability and promoted cell apoptosis significantly. However, this concentration is higher than the therapeutic concentration $(<1.5 \mathrm{mmol} / \mathrm{L})$. Though there is no significant effect at $1 \mathrm{mmol} / \mathrm{L}$, it is of interest to investigate the effects for a long time and further clinical investigation might be valuable.

\section{Conclusions}

In summary, here we found that the enormous consumption of lithium batteries could be a serious threat to the environment of the Yangtze River Basin. At the same time, we found that certain concentrations of lithium will cause damage to human cardiomyocytes. It can not only inhibit the activity of cardiomyocytes, but also promote cardiomyocyte apoptosis. Therefore, it is essential to detect lithium pollution in the environment (such as soil and water sources) and effectively recycle lithium batteries in the future.

\section{Abbreviations}

EdU: 5-Ethynyl-2'-deoxyuridine; CCK-8: Cell Counting Kit-8; PBS: Phosphate buffer saline; PCNA: Proliferating cell nuclear antigen; TP53: Tumor protein p53; GAPDH: Glyceraldehyde-3-phosphate dehydrogenase; DNA: Deoxyribonucleic acid.

\section{Acknowledgements}

Not applicable.

\section{Authors' contributions}

$J \mathrm{~L}$ conceived and designed the research; $J S$ and $X L$ performed and designed experiments, analyzed results and wrote the manuscript; XS and WW collected clinical data and performed the experiments; $\mathrm{HZ}$ and $\mathrm{XW}$ performed the experiments and analyzed the data. All authors read and approved the final manuscript.

\section{Funding}

This project has received funding from Scientific and Innovative Action Plan of Shanghai (CN) (Grant No. 19DZ2201000); Postdoctoral Research Foundation of China (Grant No. 2018M632169); The Young Program of Shanghai Municipal Health Commission (Grant No. 20194Y0458); Funded by Key Disciplines Group Construction Project of Pudong Health Bureau of Shanghai (PWZxq2017-05); Funded by Top-level Clinical Discipline Project of Shanghai Pudong District (PWYgf2018-02).

\section{Availability of data and materials \\ The data supporting the conclusions of this article are included within the article and its additional file.}

\section{Ethics approval and consent to participate}

Not applicable.

\section{Consent for publication \\ Not applicable.}

\section{Competing interests}

The authors declare that they have no competing interests.

\section{Author details}

${ }^{1}$ Key Laboratory of Arrhythmias of the Ministry of Education of China, Shanghai East Hospital, Tongji University School of Medicine, Shanghai 200120, China. ${ }^{2}$ Institute of Clinical Epidemiology and Evidence-Based Medicine, Tongji University School of Medicine, No. 1239 Siping Road, Shanghai 200092, China. ${ }^{3}$ Shanghai East Hospital, Tongji University School of Medicine, Shanghai 200123, China.

Received: 8 January 2020 Accepted: 23 March 2020

Published online: 07 April 2020

\section{References}

1. Dessemond C, Lajoie-Leroux F, Soucy G, Laroche N, Magnan JF (2019) Spodumene: the lithium market, resources and processes. Minerals. https ://doi.org/10.3390/min9060334

2. Gourcerol B, Gloaguen E, Melleton J, Tuduri J, Galiegue X (2019) Reassessing the European lithium resource potential — a review of hard-rock resources and metallogeny. Ore Geol Rev 109:494-519. https://doi. org/10.1016/j.oregeorev.2019.04.015

3. Kushnir D (2013) Lithium resource flows over time: implications and challenges. Abstr Pap Am Chem S 245

4. Kesler SE, Gruber PW, Medina PA, Keoleian GA, Everson MP, Wallington TJ (2012) Global lithium resources: relative importance of pegmatite, brine and other deposits. Ore Geol Rev 48:55-69. https://doi.org/10.1016/j. oregeorev.2012.05.006

5. Hou H, Jing M, Yang Y, Zhu Y, Fang L, Song W, Pan C, Yang X, Ji X (2014) Sodium/lithium storage behavior of antimony hollow nanospheres for rechargeable batteries. ACS Appl Mater Interfaces 6(18):16189-16196. https://doi.org/10.1021/am504310k

6. Tarascon J-M (2010) Is lithium the new gold? Nat Chem 2(6):510. https:// doi.org/10.1038/nchem.680 
7. Aral H, Vecchio-Sadus A (2008) Toxicity of lithium to humans and the environment-a literature review. Ecotoxicol Environ Saf 70(3):349-356. https://doi.org/10.1016/j.ecoenv.2008.02.026

8. Stewart AJ, Kszos LA (1996) Caution on using lithium ( $\mathrm{Li}+$ ) as a conservative tracer in hydrological studies. Limnol Oceanogr 41(1):190-191. https ://doi.org/10.4319/lo.1996.41.1.0190

9. Bonino CA, Ji L, Lin Z, Toprakci O, Zhang X, Khan SA (2011) Electrospun carbon-tin oxide composite nanofibers for use as lithium ion battery anodes. ACS Appl Mater Interfaces 3(7):2534-2542. https://doi. org/10.1021/am2004015

10. Wanger TC (2011) The lithium future-resources, recycling, and the environment. Conserv Lett 4(3):202-206

11. Vaughan A (2019) The looming electric car battery waste mountain. New Sci 244(3256):12

12. Chen J, Wu X, Finlayson BL, Webber M, Wei T, Li M, Chen Z (2014) Variability and trend in the hydrology of the Yangtze River, China: annual precipitation and runoff. J Hydrol 513:403-412. https://doi.org/10.1016/j. jhydrol.2014.03.044

13. Wang N, Tang L, Pan H (2018) Analysis of public acceptance of electric vehicles: an empirical study in Shanghai. Technol Forecast Soc Chang 126:284-291. https://doi.org/10.1016/j.techfore.2017.09.011

14. Shahzad B, Mughal MN, Tanveer M, Gupta D, Abbas G (2017) Is lithium biologically an important or toxic element to living organisms? An overview. Environ Sci Pollut Res Int 24(1):103-115. https://doi.org/10.1007/ s11356-016-7898-0

15. Sun J, Li J, Zhou T, Yang K, Wei S, Tang N, Dang N, Li H, Qiu X, Chen L (2016) Toxicity, a serious concern of thermal runaway from commercial Li-ion battery. Nano Energy 27:313-319. https://doi.org/10.1016/j.nanoe n.2016.06.031

16. Kszos LA, Beauchamp JJ, Stewart AJ (2003) Toxicity of lithium to three freshwater organisms and the antagonistic effect of sodium. Ecotoxicology 12(5):427-437

17. Shahzad B, Tanveer M, Hassan W, Shah AN, Anjum SA, Cheema SA, Ali I (2016) Lithium toxicity in plants: reasons, mechanisms and remediation possibilities - a review. Plant Physiol Biochem 107:104-115

18. Tanveer M, Wang L (2019) Potential targets to reduce beryllium toxicity in plants: a review. Plant Physiol Biochem 139:691-696

19. Tanveer M, Hasanuzzaman M, Wang L (2019) Lithium in environment and potential targets to reduce lithium toxicity in plants. J Plant Growth Regul 38(4):1574-1586. https://doi.org/10.1007/s00344-019-09957-2

20. Sharma SD, lqbal M (2005) Lithium induced toxicity in rats: a hematological, biochemical and histopathological study. Biol Pharm Bull 28(5):834-837

21. Davis J, Desmond M, Berk M (2018) Lithium and nephrotoxicity: a literature review of approaches to clinical management and risk stratification BMC Nephrol 19(1):305. https://doi.org/10.1186/s12882-018-1101-4

22. Kibirige D, Luzinda K, Ssekitoleko R (2013) Spectrum of lithium induced thyroid abnormalities: a current perspective. Thyroid Res 6(1):3. https:// doi.org/10.1186/1756-6614-6-3

23. Niethammer M, Ford B (2007) Permanent lithium-induced cerebellar toxicity: three cases and review of literature. Mov Disord 22(4):570-573

24. Ott M, Stegmayr B, Salander Renberg E, Werneke U (2016) Lithium intoxication: incidence, clinical course and renal function-a population-based retrospective cohort study. J Psychopharmacol 30(10):1008-1019. https:// doi.org/10.1177/0269881116652577

25. Mollova M, Bersell K, Walsh S, Savla J, Das LT, Park SY, Silberstein LE, Dos Remedios CG, Graham D, Colan S, Kuhn B (2013) Cardiomyocyte proliferation contributes to heart growth in young humans. Proc Natl Acad Sci USA 110(4):1446-1451. https://doi.org/10.1073/pnas.1214608110

26. Varga ZV, Ferdinandy P, Liaudet L, Pacher P (2015) Drug-induced mitochondrial dysfunction and cardiotoxicity. Am J Physiol Heart Circ Physiol 309(9):H1453-H1467. https://doi.org/10.1152/ajpheart.00554.2015

27. James WP, Caterson ID, Coutinho W, Finer N, Van Gaal LF, Maggioni AP, Torp-Pedersen C, Sharma AM, Shepherd GM, Rode RA, Renz CL, Investigators S (2010) Effect of sibutramine on cardiovascular outcomes in overweight and obese subjects. N Engl J Med 363(10):905-917. https:// doi.org/10.1056/NEJMoa1003114

28. Singh S, Loke YK, Furberg CD (2007) Long-term risk of cardiovascular events with rosiglitazone: a meta-analysis. JAMA 298(10):1189-1195. https://doi.org/10.1001/jama.298.10.1189
29. Pompili M, Vichi M, Dinelli E, Pycha R, Valera P, Albanese S, Lima A, De Vivo B, Cicchella D, Fiorillo A, Amore M, Girardi P, Baldessarini RJ (2015) Relationships of local lithium concentrations in drinking water to regional suicide rates in Italy. World J Biol Psychiatry 16(8):567-574. https://doi.org/10.3109/15622975.2015.1062551

30. Gao X, Zhou Y, Sun H, Liu D, Zhang J, Zhang J, Liu W, Pan X (2019) Effects of a spiroketal compound peniciketal $A$ and its molecular mechanisms on growth inhibition in human leukemia. Toxicol Appl Pharmacol 366:1-9. https://doi.org/10.1016/j.taap.2018.12.007

31. Chen S, Dong G, Wu S, Liu N, Zhang W, Sheng C (2019) Novel fluorescent probes of 10-hydroxyevodiamine: autophagy and apoptosisinducing anticancer mechanisms. Acta Pharm Sin B 9(1):144-156. https ://doi.org/10.1016/j.apsb.2018.08.003

32. Chen H, Pan H, Qian Y, Zhou W, Liu X (2018) MiR-25-3p promotes the proliferation of triple negative breast cancer by targeting BTG2. Mol Cancer 17(1):4. https://doi.org/10.1186/s12943-017-0754-0

33. Choe KN, Moldovan G-L (2017) Forging ahead through darkness: PCNA, still the principal conductor at the replication fork. Mol Cell 65(3):380-392

34. Freeman MP, Freeman SA (2006) Lithium: clinical considerations in internal medicine. Am J Med 119(6):478-481. https://doi.org/10.1016/j. amjmed.2005.11.003

35. Baird-Gunning J, Lea-Henry T, Hoegberg LCG, Gosselin S, Roberts DM (2017) Lithium poisoning. J Intensive Care Med 32(4):249-263. https:// doi.org/10.1177/0885066616651582

36. McKnight RF, Adida M, Budge K, Stockton S, Goodwin GM, Geddes JR (2012) Lithium toxicity profile: a systematic review and metaanalysis. Lancet 379(9817):721-728. https://doi.org/10.1016/S0140 -6736(11)61516-X

37. Vidali S, Aminzadeh-Gohari S, Vatrinet R, lommarini L, Porcelli AM, Kofler B, Feichtinger RG (2019) Lithium and not acetoacetate influences the growth of cells treated with lithium acetoacetate. Int J Mol Sci. https://doi.org/10.3390/ijms20123104

38. Lei P, Ayton S, Appukuttan AT, Moon S, Duce JA, Volitakis I, Cherny R, Wood SJ, Greenough M, Berger G, Pantelis C, McGorry P, Yung A, Finkelstein DI, Bush Al (2017) Lithium suppression of tau induces brain iron accumulation and neurodegeneration. Mol Psychiatry 22(3):396-406 https://doi.org/10.1038/mp.2016.96

39. Schrauzer GN (2002) Lithium: occurrence, dietary intakes, nutritional essentiality. J Am Coll Nutr 21(1):14-21. https://doi.org/10.1080/07315 724.2002.10719188

40. Manji HK, Moore GJ, Chen G (2000) Lithium up-regulates the cytoprotective protein $\mathrm{BCl}-2$ in the CNS in vivo: a role for neurotrophic and neuroprotective effects in manic depressive illness. J Clin Psychiatry 61(Suppl 9):82-96

41. Fountoulakis KN, Vieta E, Bouras C, Notaridis G, Giannakopoulos P, Kaprinis G, Akiskal H (2008) A systematic review of existing data on long-term lithium therapy: neuroprotective or neurotoxic? Int J Neuropsychopharmacol 11(2):269-287. https://doi.org/10.1017/S1461 145707007821

42. Chen RW, Chuang DM (1999) Long term lithium treatment suppresses p53 and Bax expression but increases $\mathrm{BCl}-2$ expression. A prominent role in neuroprotection against excitotoxicity. J Biol Chem 274(10):6039-6042. https://doi.org/10.1074/jbc.274.10.6039

43. Balasubramanian D, Pearson JF, Kennedy MA (2019) Gene expression effects of lithium and valproic acid in a serotonergic cell line. Physiol Genom 51(2):43-50. https://doi.org/10.1152/physiolgenomics.00069 2018

44. Ammari TG, Al-Zu'bi Y, Abu-Baker S, Dababneh B, Gnemat W, Tahboub A (2011) The occurrence of lithium in the environment of the Jordan Valley and its transfer into the food chain. Environ Geochem Health 33(5):427437. https://doi.org/10.1007/s10653-010-9343-5

45. Kszos LA, Stewart AJ (2003) Review of lithium in the aquatic environment: distribution in the United States, toxicity and case example of groundwater contamination. Ecotoxicology 12(5):439-447

46. Gershman M, Thurner TW (2018) New development: reinventing industrial policy a Russian study in engineering and design. Public Money Manage 38(2):157-160. https://doi.org/10.1080/09540962.2018.1407166

47. Pelegov DV, Pontes J (2018) Main drivers of battery industry changes: electric vehicles - a market overview. Batteries. https://doi.org/10.3390/ batteries 4040065 
48. Cano ZP, Banham D, Ye SY, Hintennach A, Lu J, Fowler M, Chen ZW (2018) Batteries and fuel cells for emerging electric vehicle markets. Nat Energy 3(4):279-289. https://doi.org/10.1038/s41560-018-0108-1

49. Ferensztajn-Rochowiak E, Rybakowski JK (2016) The effect of lithium on hematopoietic, mesenchymal and neural stem cells. Pharmacol Rep 68(2):224-230. https://doi.org/10.1016/j.pharep.2015.09.005

50. Maloney B, Balaraman Y, Liu Y, Chopra N, Edenberg HJ, Kelsoe J, Nurnberger Jl, Lahiri DK (2019) Lithium alters expression of RNAs in a type-specific manner in differentiated human neuroblastoma neuronal cultures, including specific genes involved in Alzheimer's disease. Sci Rep 9(1):18261. https://doi.org/10.1038/s41598-019-54076-3
51. Briggs KT, Giulian GG, Li G, Kao JPY, Marino JP (2016) A molecular model for lithium's bioactive form. Biophys J 111(2):294-300. https://doi. org/10.1016/j.bpj.2016.06.015

\section{Publisher's Note}

Springer Nature remains neutral with regard to jurisdictional claims in published maps and institutional affiliations.

\section{Submit your manuscript to a SpringerOpen ${ }^{\circ}$ journal and benefit from:}

- Convenient online submission

- Rigorous peer review

- Open access: articles freely available online

- High visibility within the field

- Retaining the copyright to your article

Submit your next manuscript at $\mathbf{s p r i n g e r o p e n . c o m ~}$ 